\title{
Complexations of Divalent Metallic Ions with Fulvic Acids
}

\author{
Denise de Oliveira $\operatorname{Vaz}^{1+}$, Andreia Neves Fernandes ${ }^{2}$ (i), Bruno Szpoganicz ${ }^{1}$ (D) \\ ${ }^{1}$ Federal University of Santa Catarina (UFSC), University Campus Reitor João David Ferreira Lima, Florianópolis, Santa Catarina, Brazil \\ ${ }^{2}$ Federal University of Rio Grande do Sul (UFRGS), 9500 Bento Gonçalves Av, Porto Alegre, Rio Grande do Sul, Brazil \\ + Corresponding author: Denise de Oliveira Vaz, e-mail address: denisevaz.business@gmail.com
}

$\begin{array}{ll}\text { ARTICLE INFO } & \\ & \text { Keywords: } \\ \text { Article history: } & \text { 1. fulvic acids } \\ \text { Received: September 4, } 2017 & \text { 2. SRFA } \\ \text { Accepted: May 23, 2018 } & \text { 3. copper } \\ \text { Published: May 29, } 2018 & \text { 4. cadmium } \\ & \text { 5. zinc }\end{array}$

ABSTRACT: In this work, the interactions of the functional groups of fulvic acids with copper, cadmium and zinc bivalent ions was investigated by potentiometry. The BEST7 software was employed to investigate the interactions of the functional groups. The software SPE and SPEPLOT were used to generate and to plot the species diagrams. It was used the Suwannee River fulvic acid (SRFA) of the IHSS (International Humic Substances Society) to illustrate the process. The values of the proton dissociation and complexation constants with the divalent ions for each functional group were calculated and their values were very close to those previously published. The functional group present in the highest quantity in the complexes was catechol, and it is complexed with all the divalent ions, although with $\mathrm{Cu}$ (II). According to the results obtained by potentiometry, the reactivity series for the divalent ions and the SRFA is: $\mathrm{Cu}$ (II) $>\mathrm{Cd}$ (II) $>\mathrm{Zn}$ (II). Thus, the method employed could be useful to estimate the role of fulvic acids in the transport of metals in the aquatic environments.

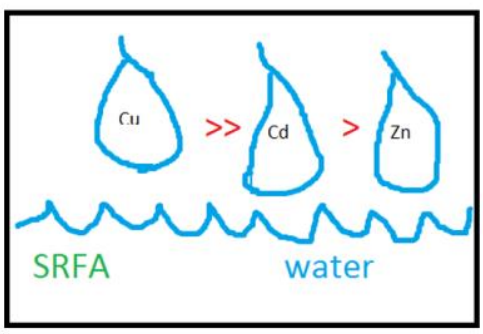

The potentiometric results allow to indicate the following reactivity order of the divalent ions with the SRFA (Suwannee River fulvic acids): $\mathrm{Cu}(\mathrm{II})>>\mathrm{Cd}(\mathrm{II})>\mathrm{Zn}(\mathrm{II})$.

\section{Introduction}

The study of the complexation of potential toxic metals at natural systems by substances as fulvic acids, which are in fresh-waters, for example, is important because these reactions can determine the metal speciation and bioavailability of the metal species. The metal speciation also can determine the mobility of trace metals in the ecosystems $\mathrm{s}^{1,2}$. Free metal ions are more toxic to aquatic biota than metal ions bound to organic molecules like the fulvic acids ${ }^{3}$. The zinc, for example, is one of the essential metals for the cycle of life of the organisms, but it can be harmful when its concentrations overpass the limits required for a healthy nutrition ${ }^{4}$. Heavy metals, as zinc, have the ability to accumulate in living tissues throughout the food chain. Fish can become the main form of population transfer to these elements, since they are capable of bioaccumulation and bioconcentration ${ }^{5}$. Copper and cadmium appear in the ecosystems as contaminants independent of their concentration or oxidation number. Cadmium, copper and zinc are prevalent in nature due to their high industrial use, and they can affect growth of plants, according their metal concentration. Their bioavailability is influenced by physical factors such as temperature, phase association, adsorption and sequestration. These metallic elements are considered systemic toxicants that are known to induce multiple organ damage, even at lower levels of exposure. Being classified as human carcinogens according to the U.S. Environmental Protection Agency ${ }^{6-11}$. One of the best manners to study the metals interactions with fulvic acids is the using of analyses techniques in solution, as potentiometric titration, because it 
can reproduce as closer as possible what occurs in the nature systems. In this work, to elucidate the titration curves of the fulvic acids and zinc (II), cadmium (II) and copper (II) ion complexation it was used the BEST7 software and the software SPE and SPEPLOT.

\section{Experimental setup}

All the reagents were analytical grade and were used without purification. It was used the SRFA (Suwannee River Fulvic Acid, IR101F) purchased from the IHSS. The solutions of SRFA $(80.00 \mathrm{mg}$ $\mathrm{L}^{-1}$ ) were prepared in the titration cell, dissolving the quantity of SRFA in water, adding $8.00 \mathrm{~mL}$ of $0.01 \mathrm{~mol} \mathrm{~L}^{-1} \mathrm{HCl}$ and completing the volume with double distilled water to $50.00 \mathrm{~mL}$. The stock solutions of $0.01 \mathrm{~mol} \mathrm{~L}^{-1} \mathrm{CuCl}_{2} \cdot 2 \mathrm{H}_{2} \mathrm{O}, \mathrm{CdCl}_{2} \cdot \mathrm{H}_{2} \mathrm{O}$ and $\mathrm{Zn}\left(\mathrm{NO}_{3}\right)_{2} .6 \mathrm{H}_{2} \mathrm{O}$ (Vetec Química Fina Ltda.) were standardized by titration with EDTA (Merck), $1.0 \times 10^{-2} \mathrm{~mol} \mathrm{~L}^{-1}$ using murexide as indicator and buffer solution $\mathrm{pH}=8$. The titration agent was carbonate-free solution of $0.100 \mathrm{~mol} \mathrm{~L}^{-1} \mathrm{KOH}$. The titrations were carried out in a thermostated bath $\left(25.00 \pm 0.05{ }^{\circ} \mathrm{C}\right)$ sealed cell, in an inert atmosphere (argon gas). The experiments started in $\mathrm{pH} 3.0$ (triplicates). The $\mathrm{pH}$ values of titrations were read using a pHmeter (Corning 350). It was used the BEST7 software to resolve the equilibrium data because it was developed to can be useful to refine the stability constants from potentiometric data of any kind of system with any number of interactions components. To generate the species diagrams it was used the SPE software and to plot them it was used the SPEPLOT software

\section{Results and discussion}

In the previous paper ${ }^{12}$, it was determined the quantities of the functional groups of the SRFA. In this paper and using those values, it was determined by potentiometry titrations the complexations with divalent metallic ions. In the Table 1, is presented the values of the complexation constants of the ions $\mathrm{Cu}$ (II), $\mathrm{Zn}$ (II) and $\mathrm{Cd}(\mathrm{II})$ to the functional groups of the SRFA.

Table 1. Equilibrium constants (log $\mathrm{K}$ ) to the ions $\mathrm{Cu}(\mathrm{II}), \mathrm{Cd}(\mathrm{II})$ and $\mathrm{Zn}$ (II) and to the ligands phenol (A), benzoic (B), catechol (C), phthalic (D) and salicylic (E) of the SRFA

\begin{tabular}{|c|c|c|c|c|c|}
\hline Species & $A(\log K)$ & B $(\log K)$ & $C(\log K)$ & $D(\log K)$ & $E(\log K)$ \\
\hline \multicolumn{6}{|l|}{$\mathrm{Cu}(\mathrm{II})$} \\
\hline$[\mathrm{CuL}] /[\mathrm{Cu}] .[\mathrm{L}]$ & $\begin{array}{l}7.62 \square 0.07 \\
(*)\end{array}$ & $\begin{array}{l}(-) \\
(1.60 \square 0.01)\end{array}$ & $\begin{array}{l}13.42 \square 0.05 \\
(13.00 \square 0.06)\end{array}$ & $\begin{array}{l}(-) \\
(3.22 \square 0.03)\end{array}$ & $\begin{array}{l}11.13 \square 0.02 \\
(10.62 \square 0.02)\end{array}$ \\
\hline$\left[\mathrm{CuL}_{2}\right] /[\mathrm{Cu}] \cdot\left[\mathrm{L}^{2}\right]$ & $(-)$ & $(-)$ & $\begin{array}{l}25.39 \square 0.08 \\
(24.90 \square 0.10)\end{array}$ & $\begin{array}{ll}(-) \\
(5.46 \square 0.04)\end{array}$ & $\begin{array}{l}18.95 \square 0.05 \\
(18.45 \square 0.01)\end{array}$ \\
\hline \multicolumn{6}{|l|}{$\mathrm{Cd}(\mathrm{II})$} \\
\hline$[\mathrm{CdL}] /[\mathrm{Cd}] .[\mathrm{L}]$ & $(-)$ & $\begin{array}{l}(-) \\
(1.40 \square 0.01) \\
\end{array}$ & $\begin{array}{l}8.81 \square 0.03 \\
(8.20 \square 0.01) \\
\end{array}$ & $\begin{array}{l}2.60 \square 0.05 \\
(2.50 \square 0.01) \\
\end{array}$ & $(-)$ \\
\hline$[\mathrm{CdOHL}] .[\mathrm{H}] /[\mathrm{CdL}$ & $(-)$ & $(-)$ & $\begin{array}{l}0.28 \square 0.02 \\
(*)\end{array}$ & $(-)$ & $(-)$ \\
\hline$\left[\mathrm{CdL}_{2}\right] /[\mathrm{Cd}] .\left[\mathrm{L}^{2}\right]$ & $(-)$ & $(-)$ & $\begin{array}{l}16.78 \square 0.03 \\
(*)\end{array}$ & $(-)$ & $(-)$ \\
\hline \multicolumn{6}{|l|}{$\mathrm{Zn}(\mathrm{II})$} \\
\hline$[\mathrm{ZnL}] /[\mathrm{Zn}] .[\mathrm{L}]$ & $(-)$ & $\begin{array}{l}(-) \\
(0.90 \square 0.02)\end{array}$ & $\begin{array}{l}10.05 \square 0.02 \\
(9.90 \square 0.01)\end{array}$ & $(-)$ & $(-)$ \\
\hline$[\mathrm{ZnOHL}] .[\mathrm{H}] /[\mathrm{ZnL}]$ & $(-)$ & $(-)$ & $\begin{array}{l}0.48 \square 0.09 \\
(*)\end{array}$ & $(-)$ & $(-)$ \\
\hline$\left[\mathrm{ZnL}_{2}\right] /[\mathrm{Zn}] .\left[\mathrm{L}^{2}\right]$ & $(-)$ & $(-)$ & $\begin{array}{l}17.91 \square 0.09 \\
(17.40 \square 0.30)\end{array}$ & $(-)$ & $(-)$ \\
\hline
\end{tabular}

Where $\mathrm{L}$ (represents $=\mathrm{A}, \mathrm{B}, \mathrm{C}, \mathrm{D}$ and $\mathrm{E}$ ). The values of the literature are listed between parenthesis ${ }^{13,14}$.

Note: The symbol (-) represents that the respective values were not observed experimentally and (*) are the values not published.

The values of the complexation constants to the $\mathrm{Cu}(\mathrm{II})$ and the values of the literature were similar ${ }^{7}$, 
${ }^{8}$ although the values of the $\log \mathrm{K}$ to the salicylate groups are slightly higher when are connected to the structure of the fulvic acids. It can be the factor on why the experimental values are higher than the values of the salicylic acid groups (simple substance). At this way, some differences are previewed due to the fact of the SRFA is a mixture so complex. The phenolic ligands are important as constituents of the complexes humic substances, on which are the main ligands, getting responsible in the transport and taking part in the transport and accumulation of the nutrients. Describe that in humic substances can exist functional groups as salicylate and the strong acidity of the salicylic groups can be due by the formation of structures of five member with intermolecular hydrogen bonds between the phenolic groups and the anion carboxylate. Evidences of this would be the fact that $\log \mathrm{K}$ of the ML species (salicylate) diminishes 1.5 units and the $\log \mathrm{K}$ of the $\mathrm{ML}_{2}$ species (salicylic) increases 3 units, increasing the ionization of the first proton and weakening the acidity of the second proton. Steric effects are significant in the increase of the influence of the hydrogen linkages in the SRFA percentage. In Figure 1 is presented the graphic of distribution percentage of species of the SRFA complexed with $\mathrm{Cu}(\mathrm{II})$ versus $\mathrm{p}[\mathrm{H}]$.
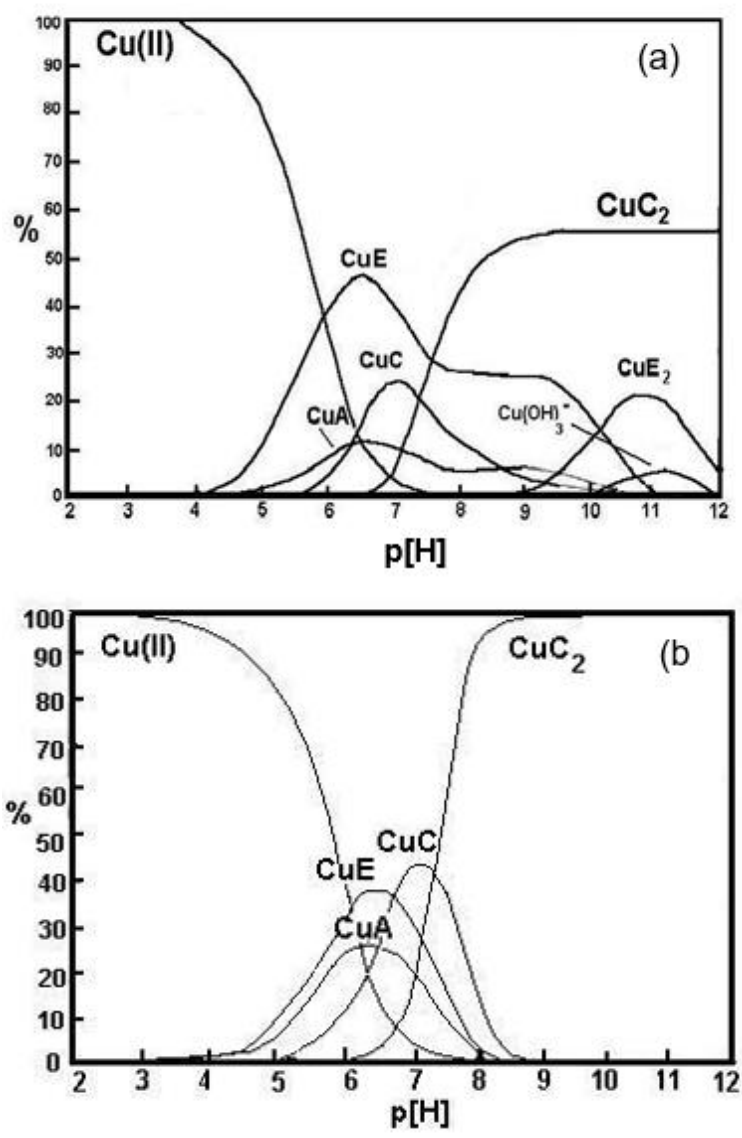

Figure 1. The percentage of species of SRFA with the $\mathrm{Cu}$ (II) versus $\mathrm{p}[\mathrm{H}]$ in $\mathrm{V}_{\mathrm{sol} \mathrm{CuCl} 2}=2$ (a) and in $\mathrm{V}_{\mathrm{sol} \mathrm{CuCl} 2}=$ $0.5 \mathrm{~mL}$, where: phenol groups $(\mathbf{A})$; benzoic groups $(\mathbf{B})$; catechol groups (C); phthalic groups (D) and salicylic groups $(\mathbf{E})$. (Conditions: $\mu=0.100 \mathrm{~mol} \mathrm{~L}^{-1} \mathrm{KCl}$; $\mathrm{T}=$ $\left.25^{\circ} \mathrm{C} ; \mathrm{C}_{\mathrm{SRFA}}=93 \mathrm{mg} \mathrm{L}^{-1} ; \mathrm{C}_{\mathrm{sol} \mathrm{CuCl} 2}=10^{-2} \mathrm{~mol} \mathrm{~L}^{-1}\right)$.

In Figure 1 , at $\mathrm{p}[\mathrm{H}]=4$ its begins the complex $\mathrm{CuE}$ (Where: $\mathrm{E}=$ salicylic) reaching its maximum amount of $48 \%$ at $\mathrm{p}[\mathrm{H}]=6.5$. After appearing the $\mathrm{CuA}$ species (where: $\mathrm{A}=$ phenolic), at $\mathrm{p}[\mathrm{H}]=6.5$ it has $11 \%$. The specie $\mathrm{CuC}$ (where: $\mathrm{C}=$ catechol) is at $\mathrm{p}[\mathrm{H}]=5.5$ with the maximum of concentration of $22 \%$ at $\mathrm{p}[\mathrm{H}]=7.0$. The specie $\mathrm{CuC}_{2}$ begins at $\mathrm{p}[\mathrm{H}] 6.6$ ranging the maximum of $58 \%$ at $\mathrm{p}[\mathrm{H}]=9$. The specie $\mathrm{CuE}_{2}$ begins at $\mathrm{p}[\mathrm{H}]=9.0$ and is on the top of $20 \%$ at $\mathrm{p}[\mathrm{H}]=10.8$. At $\mathrm{p}[\mathrm{H}] 10$ begins the hydroxide species with $\mathrm{Cu}(\mathrm{II})$. In Figure 1 (b) it is possible to observe the complexation with $\mathrm{Cu}$ (II) begin at $\mathrm{p}[\mathrm{H}] 4$, beginning the $\mathrm{CuE}$ and $\mathrm{CuA}$ species reaching their maximum at $\mathrm{p}[\mathrm{H}]=6.5$ $(38 \%)$ and $\mathrm{p}[\mathrm{H}]=6.2(25 \%)$. The specie $\mathrm{CuC}$ begins its formation at $\mathrm{p}[\mathrm{H}]=5$, reaching its maximum at $\mathrm{p}[\mathrm{H}]=7.0(43 \%)$. The specie $\mathrm{CuC}_{2}$ begins at $\mathrm{p}[\mathrm{H}]=6.0$ reaching the maximum at $\mathrm{p}[\mathrm{H}]=8(98 \%)$. 
In Figure 2, it can be observed 4 complexes for the $\mathrm{Zn}(\mathrm{II})$ and the functional groups of SRFA. At $\mathrm{p}[\mathrm{H}]=4$ appears the $\mathrm{ZnD}$ species $(22 \%$ at $\mathrm{p}[\mathrm{H}]=6.5)$, at $\mathrm{p}[\mathrm{H}]=6.8$ is formed the $\mathrm{ZnC}$ species $(75 \%$ at $\mathrm{p}[\mathrm{H}]=8.5)$. At $\mathrm{p}[\mathrm{H}] 7.8$ the hydroxy species $\mathrm{ZnOHC}(\operatorname{maxim} 33 \%$ at $\mathrm{p}[\mathrm{H}]=10$. The $\mathrm{ZnC}_{2}$ species is formed after $\mathrm{p}[\mathrm{H}]=8$ (maximum $60 \%$ at $\mathrm{p}[\mathrm{H}]=10.5)$.

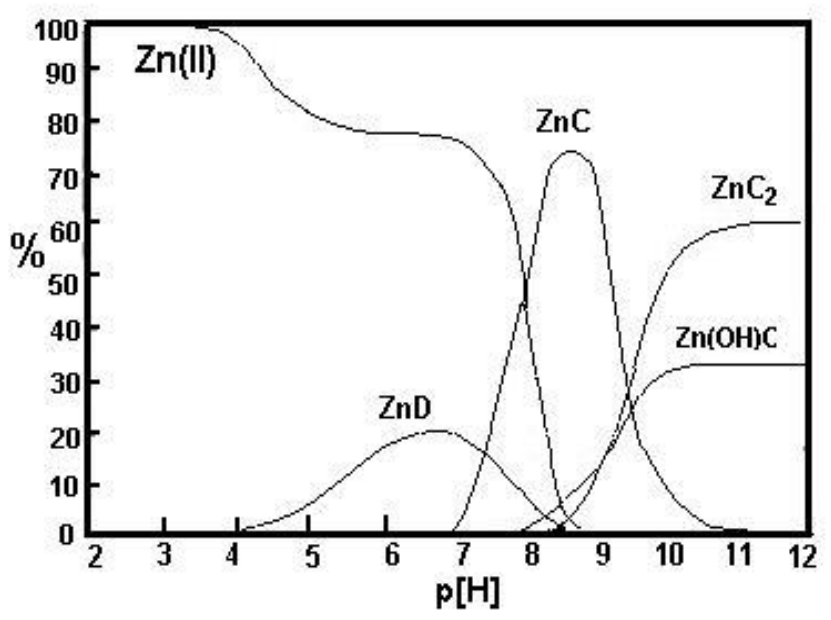

Figure 2. Percentage of SRFA species with $\mathrm{Zn}(\mathrm{II})$ versus $\mathrm{p}[\mathrm{H}]$, where the ligands are represented by phenol (A), benzoic (B), catechol (C), phthalic (D) and salicylic (E). (Conditions: $\mu=0.100 \mathrm{~mol} \mathrm{~L}^{-1} \mathrm{KCl} ; \mathrm{T}=25^{\circ} \mathrm{C}$; $\left.\mathrm{C}_{\mathrm{SRFA}}=93 \mathrm{mg} \mathrm{L}^{-1}, \mathrm{C}_{\mathrm{sol} \mathrm{Zn}(\mathrm{NO} 3) 2}=10^{-2} \mathrm{~mol} \mathrm{~L}^{-1}\right)$.

The Figure 3 shows the graphic of distribution of species of the fulvic acid complexed with the $\mathrm{Cd}(\mathrm{II})$ in percentage versus $\mathrm{p}[\mathrm{H}]$. The $\mathrm{Cd}(\mathrm{II})$ presented a chemical behavior very similar to the $\mathrm{Zn}$ (II) forming the same type of forming. The species formed with the $\mathrm{Cd}$ (II) are the $\mathrm{CdD}$ (where: $\mathrm{D}=$ phthalic) reaching its maximum of $7 \%$ at $\mathrm{p}[\mathrm{H}]=7$; at $\mathrm{p}[\mathrm{H}]=7.2$ is formed the $\mathrm{CdC}$ species (where: $\mathrm{C}=$ catechol), reaching its maximum $28 \%$ at $\mathrm{p}[\mathrm{H}]=8.8$; at $\mathrm{p}[\mathrm{H}]=8$ it was formed the hydroxy species $\mathrm{CdOHC}$, reaching its maximum of $80 \%$ at $\mathrm{p}[\mathrm{H}]=8.0$, over the $\mathrm{p}[\mathrm{H}]=8.2$ it was formed the $\mathrm{CdC} 2$ species reaching its maximum of $30 \%$ at $\mathrm{p}[\mathrm{H}]=10.9$. The catechol was the functional group more reactive with all the divalent ions studied, it has complexed with all the ions. At second place, it was the salicylic group complexed in great quantity with the ions $\mathrm{Cu}$ (II). According the results of this work, this is the series of reactivity to the bivalents ions and the SRFA: $\mathrm{Cu}$ (II) $>\mathrm{Cd}$ (II) $>\mathrm{Zn}$ (II).

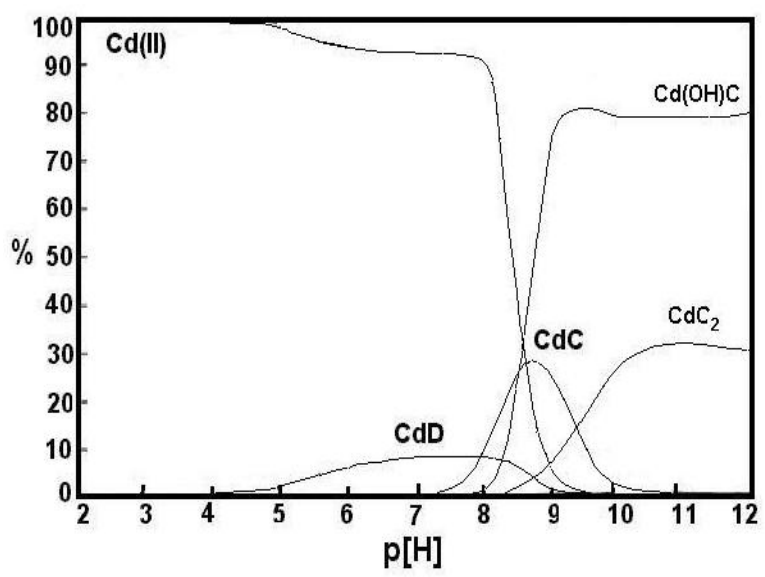

Figure 3. Percentage of species of the SRFA with $\mathrm{Cd}$ (II) versus $\mathrm{p}[\mathrm{H}]$. Where: phenol (A), benzoic (B), catechol (C), phthalic (D) and salicylic (E). (Conditions: $\mu=0.100 \mathrm{~mol} \mathrm{~L}^{-1} \mathrm{KCl} ; \mathrm{T}=25^{\circ} \mathrm{C} ; \mathrm{C}_{\mathrm{SRFA}}=93 \mathrm{mg} \mathrm{L}^{-1}$; $\mathrm{C}_{\mathrm{sol} \mathrm{CdCl} 2}=10^{-2} \mathrm{~mol} \mathrm{~L}^{-1}$ ).

\section{Conclusions}

The values of the proton dissociation and complexation constants with the divalent ions for each functional group were calculated and their values were very close to those of the literature. The functional group present in the highest quantity in the complexes was catechol, and it complexed with all the divalent ions, although to a greater extend with $\mathrm{Cu}(\mathrm{II})$. According to the results obtained by potentiometry, the reactivity series for the divalent ions and the SRFA is: $\mathrm{Cu}$ (II) $>>\mathrm{Cd}$ (II) $>\mathrm{Zn}(\mathrm{II})$.

\section{Acknowledgments}

Thanks to $\mathrm{CNPq}$ (Conselho Nacional de Desenvolvimento Científico e Tecnológico) and FUNCITEC (Foundation of Science and Technology).

\section{References}

[1] Ephraim, J. H. Heterogeneity as a concept in the interpretation of metal ion binding by humic substances. The binding of zinc by aquatic fulvic acid. Analytica Chimica Acta 267 (1) (1992) 3945. https://doi.org/10.1016/0003-2670(92)85004-P

[2] Bacstrom, M, Dario, M, Karlsson, S, Allard, B. Effects of a fulvic acid on the adsorption of mercury and cadmium on goethite. Science of the total Environment 364 (1-3) (2003) 257-268. 
https://doi.org/10.1016/S0048-9697(02)00573-9.

[3] Eprahim J. H., Marinsky, J. A., Cramer, S. J. Complex-forming properties of natural organic acids: fulvic acids complexes with cobalt, zinc and europium. Talanta 36 (4) (1989) 439-443. https://doi.org/10.1016/0039-9140(89)80225-5.

[4] Toxicological Profile for Zinc. National Technical Information Service (NTIS), USA, 1989 $142 \mathrm{p}$.

[5] Nantsis, E. A., Carper, W. R. Molecular Structure of divalent metal-ion-fulvic acids complexes. Journal of Molecular Structure 423 (3) (1998) 203-212. https://doi.org/10.1016/S01661280(97)00125-5.

[6] Merabito, E., Radaelli, M, Corami, F., Turella, C., Toscano, G., Copodagliom G. Temporal evolution of cadmium, copper and lead concentration in the Venice lagoon. Water in relation with the speciation and dissolved/particulate partition. Marine Pollution Bulletin (in press). 129 (2) (2018) 884-892. https://doi.org/10.1016/j.marpolbul.2017.10.043.

[7] Wang, F., Xu, S., Zhou, Y., Wang, R., Zhang., Trace elements exposure of whooper swans (Cygnus cygnus) wintering in a marine lagoon (Swan lake), northern China. Marine Pollution Bulletin, 119, (2) (2017) 60-67. https://doi.org/10.1016/j.marpolbul.2017.03.063.

[8] Hernández-Crespo, C., Martín, M. Determination of Background levels and pollution assessment for seven metals $(\mathrm{Cd}, \mathrm{Cu}, \mathrm{Ni}, \mathrm{Pb}, \mathrm{Zn}$, $\mathrm{Fe}, \mathrm{Mn}$ ) in sediments of a Mediterranean coastal lagoon. Catena, 133 (2015) 206-214. https://doi.org/10.1016/j.catena.2015.05.013.

[9] Taria, J., Devenport, J., Townley, B., Dorador, C., Schneider, B., Tolorza, V., Von Turnpling W., Sources enrichment and redistribution of As, Cd, $\mathrm{Cu}, \mathrm{Li}, \mathrm{Mo}$ and $\mathrm{Sb}$ in the northern Atacama Region Chile: Implications for acid watersheds affected by mining. Journal of Geochemical Exploration, 185 (2018) $33-51$. https://doi.org/10.1016/j.gexplo.2017.10.021.

[10] Sargentini Jr., E., Rocha, J. C., Rosa, A. H., Zara, L. F., dos Santos, A. Substâncias Húmicas Aquáticas: Fracionamento molecular e caracterização de rearranjos internos após complexação com íons metálicos. Química Nova, 24, (3) (2001), 339-344. https://doi.org/10.1590/S010040422001000300010.

[11] Yan, M., Dryer, D., Karshin, G.V., Benedetti, M.F., In situ study of binding of copper by fulvic acid: comparison of differential absorbance date and model predictions. Water Research, 47, (2), (2013) 588-596. https://doi.org/10.1016/j.watres.2012.10.020.

[12] Vaz, D. O., Fernandes, A. N., Szpoganicz, B; Sierra, M. M. D. Potentiometric quantification and speciation of oxygenated groups in humic substances using Best7 software. Eclét. Quím. 35 (4) (2010) 147-152. https://doi.org/10.1590/S010046702010000400019.

[13] Martell, A. E., Smith, R. M. Critical Stability Constants. Plenum Press, Ed., New York, $1^{\text {st }}$ ed. 1982, ch.4.

[14] Martell, A. E., Hancock, R. D. Metal Complexes in Aqueous Solutions, Plenum Publishing Corporation, New York, $1^{\text {st }}$ ed. 1996, ch. 3 . 